\title{
SINGING AS AN EFFECTIVE APPROACH FOR LEARNING ENGLISH ON EARLY CHILDHOOD
}

\author{
Ro'ifah \\ English Department FKIP UMSurabaya \\ Email: roifah2fe@gmail.com
}

\begin{abstract}
There are so many native languages in Indonesia that makes English as a foreign language following Indonesian as the L2. This leads to the development of simultaneous bilinguals. However, there have been some contradictory opinions on whether learning English for early childhood is effective as it can inhibit a child's L1 and L2 development. This may lead to the phenomenon of subtractive bilingualism resulting in a major dilemma for the government and parents. However, this notion can be debated through the critical period hypothesis. This study presents a literature review on 'rhymes, songs, and chant's as the effective media for learning English and its implication for early childhood through 'singing' approach.
\end{abstract}

Keywords: chants, critical period, early childhood, rhymes, songs

\begin{abstract}
ABSTRAK
Ada begitu banyak bahasa asli di Indonesia yang menjadikan bahasa Inggris sebagai bahasa asing mengikuti bahasa Indonesia sebagai L2. Ini mengarah pada pengembangan bilingual secara simultan. Namun, ada beberapa pendapat yang bertentangan tentang apakah belajar bahasa Inggris untuk anak usia dini efektif karena dapat menghambat perkembangan L1 dan L2 anak. Ini dapat mengarah pada fenomena bilingualisme subtraktif yang mengakibatkan dilema besar bagi pemerintah dan orang tua. Namun, gagasan ini dapat diperdebatkan melalui hipotesis periode kritis. Studi ini menyajikan tinjauan literatur tentang 'sajak, lagu, dan nyanyian sebagai media yang efektif untuk belajar bahasa Inggris dan implikasinya untuk anak usia dini melalui pendekatan' menyanyi '.
\end{abstract}

Kata kunci: nyanyian, masa kritis, anak usia dini, sajak, lagu

In this disruption era, English has

\section{INTRODUCTON}

English is an international language that has an important role in everyday life. English is commonly used in education, work, entertainment, electronic communication, and travel, so English is very important to master. Nowadays, it has become a common thing that people can use English. That is, people who come from diverse backgrounds, origin, religion and culture have an agreed media to communicate with each other in the international world, namely English. also been used as a language of

communication from an early age. These demands make parents competing to enter their children into schools that use English as a medium of language in learning. Lately, learning English as a foreign language in Indonesia has begun to reach the level of early childhood education (Sulistyo, 2009).

In accordance with UU No. 20 of 2003 concerning the National Education System, Chapter 1, Article 1, Item 14, Early Childhood Education (PAUD) is a coaching 
effort aimed at children from birth to age 6 through the provision of educational stimuli to help growth and physical and spiritual development so that children have readiness to enter further education. This is explained in more detail in Article 28 on Early Childhood Education stating that: (1) PAUD is held before the Basic Education level, (2) PAUD can be held through formal, non-formal and / or informal education channels, (3) PAUD education channels formal: kindergarten / RA or other forms of equivalent, (4) PAUD non-formal education pathway: KB (play group), TPA (Al-Qur'an Kindergarten), or other equivalent forms, and (5) PAUD informal education path: family education or education organized by the environment.

Introducing English early on for Indonesian children can be assumed as support for the statement of the Minister of Education and Culture of the Republic of Indonesia on the commemoration of National Education Day on May 2, 2013. Minister of Education and Culture, Mohammad Nuh, declared the golden generation as the theme of the 2013 National Education Day celebration. The declaration was based on the fact that from 2010 to 2035 Indonesia received a demographic bonus, the largest productive age population in the country's history.

Massive investment in the field of human resource development will be carried out as an effort to welcome 100 years of Indonesia's independence, in the next 2045. The Minister of Education and Culture also supports the Paudnisasi movement, to encourage the expansion of access to education at all levels in an effort to revive the golden generation. Good and equitable quality of education is the key to successfully raising the golden generation (http: //education.kompas.com / read / 2012/05/02/1324267
Kemdikbud.Ingin.Cetak.Generasi.Gasas available: Wednesday 2 May 2013).

According to experts, age before entering basic age is a golden age (golden age) and is a critical period in the stages of human life that will determine the child's next development. All aspects of language use should be introduced to children before this golden period is over. At this age, it is very important to introduce good and correct language because using good and right language is very useful for communicating with the environment.

The development of children's language has actually begun since the child was born using the simplest language or speech that is 'crying', then the development in the form of 'babble / babble', simple words / sentences accompanied by body movements / conditions as a complement to speech. In educational psychology there is a learning theory that can be used as a basis for teaching. To realize this, educational institutions for early childhood such as PAUD and kindergarten have the function as developers of various potentials possessed by early childhood. The potential includes a variety of abilities, one of which is the ability of language.

The declaration of the golden generation needs to be followed up by introducing English early on, because English is an international language. The mastery of English is a vehicle for global and global engagement. By introducing English as early as possible, it means to equip the people of the nation to be able to navigate the world of science and technology freely, but still prioritize the national culture.

Learning English for children at PAUD level is in line with the opinions of experts, who say that in fact the ability of early childhood is more brilliant than what is imagined by adults! They can do the sums before they are able to count. They can 
understand a hundred words before they are able to speak fluently. And at the age of three months their memory is very high, higher than what is imagined by adults (Cole \& Cole, 2001).

However, there is an assumption that attempts to introduce foreign languages to young children will interfere with language development. Provision of English in early childhood is very encouraging, but on the other hand, concerns have arisen because there are allegedly still many deficiencies in the appropriate methods and materials that will be given to early childhood. Moreover, technically, in its implementation, the role of the teacher and the policies of each institution determine how learning English as a foreign language for young children is held.

This study provides an overview of the reasons for effectively introducing English early on and the efforts that can be made. The discussion includes three things, namely the theoretical framework about early childhood (AUD) development; language development in early childhood; and effective efforts to introduce English through 'songs, ryme, and chants' to children from an early age.

\section{METHODE}

The research method used in this study is a research design using a qualitative research approach. Qualitative research, according to Moleong, is research that intends to understand phenomena about what is experienced by research subjects such as behavior, perception, motivation, actions, etc. holistically, and by means of descriptions in the form of words and language, in a special contexts that are natural and by utilizing various scientific methods.

This type of research is descriptive research. Descriptive research method is research that does not require administration and control of treatment. This research is not intended to test certain hypotheses, but only describe 'what is' about a variable, phenomenon or condition.

This study is a library research conducted in a library that collects data on effective English learning for children of din age. In addition, data is also found in bookstores and the Internet. Of the various places, the library is the most data-rich and easy to find.

The presence of researchers in this study is very important because in qualitative research the position of the researcher is quite complex as well as a planner, implementing data collection, analysis, interpretation of data, and in the end he becomes a reporter on the results of his research. So it is appropriate if the understanding of the instrument or research tool here is given to researchers because it becomes everything of the entire research process.

\section{AN EFFECTIVE WAY TO LEARN ENGLISH FOR EARLY AGE}

\section{Theory of Chilhood Development and Language Development}

Getting to know early childhood is to study their physical, cognitive, mental, and social development which will continue to develop as they age (Cole \& Cole, 2001). By knowing early childhood and various aspects that influence their development, it will be easier to explore who is an early age and how to treat them. Understanding of early childhood will be a guide for teachers in teaching them, including teaching foreign languages, in this case English. That is why theories about early childhood are needed before arriving at theories about teaching English to early childhood.

Some experts include John Dewey, Maria Montessori, Erik Erikson, Jean Piaget, and Lev Vigotsky explaining various related theories about early childhood. 
According to John Dewey, early childhood requires active and interactive learning tools, which are child-centered. While Maria Montessori stated that early childhood should be accompanied by an environment full of beauty, order, and comfort, and according to the child's senses (Mooney, 2000).

Erikson argues that early childhood is very critical in terms of the development of trust (autonomy), autonomy (autonomy) or independence, and initiatives. A child who has high confidence in himself and his environment will easily adapt to his environment. This trust is created when a newborn child feels comfort around him physically, mentally, and spiritually. This condition is needed for children in learning English.

Jean Piaget divides child development into several stages. Early childhood is in the preoperational stage. At this stage the child can judge something based on the reality that is displayed through symbols including pictures, words, and cues. Thus the child can think of something about objects or objects or events without presenting the object in front of the child. But at this stage children are still often confused about causal relationships (Cole \& Cole, 2001: 344). Piaget further stated that early childhood are more able to collect information through what they experienced themselves, than if told to him.

Vygotsky emphasizes the process of language acquisition in children through dialogue or conversation. Through conversation or dialogue, adults transfer the knowledge contained in culture to children. During the learning process, the language used by children becomes a means of intellectual transformation. By repeating, or imitating the utterances used by parents, children learn the language and culture of their parents. This process is what Vygotsky meant as the theme of development in the internalization process.

The various opinions expressed by the experts above represent the presentation of early childhood development. The introduction of early childhood thinking skills will provide an understanding of efforts to introduce English to early childhood.Cameron (2001) suggests that early childhood has unique advantages, which differ from learners at a higher level, or adults. The uniqueness and strength found in early childhood is the great potential possessed by children to learn, beyond what can be imagined or understood by adults.

The development of language recognizes four main theories, namely the behavioristic theory put forward by B.F. Skinner, the nativistic theory put forward by Noam Chomsky, the empirical theory as opposed to the nativistic theory, as well as the interaction theory. These four theories will be discussed separately in the next paragraph.

Behavioristic theory put forward by B. F. Skinner states that language is learned through conditioning by providing reinforcement and imitation (Cameron, 2001). Strengthening occurs because of the repetition of the stimulus given. The emphasis on this theory is that every child at birth does not have the innate ability to master or understand a particular linguistic structure.

Children are born into this world like a piece of clean white cloth, and the environment is what will shape all the skills of behavior including the skills of lingual behavior. The formation of these skills occurs through experience and learning processes. Noam Chomsky put forward the nativistic theory in language development. This theory states that all children since birth have the ability to speak known as the LAD (Language Acquistion Device), which 
is the potential for self-language that enables children to produce a sentence consisting of words that they already know. This statement is based on the view that states what the child hears - linguistic input - is sufficient to explain them to the language learning stage (Cameron, 2001).

Unlike the behavioristic theory, which states that children's language proficiency is shaped by the influence of their environment, this theory assumes that language is a biological gift. Language is too complex and impossible to learn in a relatively short time. So some important aspects concerning the language system must already exist in every child at birth.

Empirical theory contradicts what was stated by Chomsky. This theory suggests that the linguistic input received by children is not sufficient enough so that it cannot be said that children have LAD in language acquisition. The characteristics of this theory appear in the construction of language models studied and aspects of linguistics produced by children. Empirical theory is strongly influenced by statistical learning theory (Goffman, 1992).

In philosophy, empiricism is a theory of knowledge which states that knowledge arises from experience. Empiricism is one of the many views that focus on human knowledge, known as epistemology. Empiricism emphasizes the role of experience and proof, especially sensory perception in shaping ideas (Goffman, 1992).

The fourth theory is perspective theory, which consists of two components. Perspective theory is a combination of the two previous theories, namely the theory of nativism and the theory of behaviorism. This theory consists of two components, namely the information process that is tested through statistics as the first component. This statistical data will show that the brain has a very high ability to detect various patterns. The second component is social interaction which emphasizes a strong desire in a person to understand others and to be understood by others. Interactionism is a micro-sociology that believes that meaning is produced through individual interaction. Social interaction through a face-to-face process consists of actions, reactions, and mutual adaptation between two or more individuals.

Interaction applies to all languages, including body language and attitude. The purpose of social interaction is to communicate with others. If an ongoing interaction is threatened to end before one of the individuals involved wants it, the interaction can continue regardless of the disturbing thing or problem that arises. Erving Goffman (1992) underlines the importance of control in interactions. One must try to control the attitude of others during the interaction in order to absorb the information needed and to control the imagination of one's own perception. Important concepts included in interaction theory are the 'social role', and the 'self presentation' view put forward by Goffman.

\section{Critical Period Hypothesis}

The critical period hypothesis states that linguistic development needs to be activated between 3-12 years of age for normal development to occur (Lenneberg, 1967, cited in Hamers and Blanc). This implies that if a person is to learn language beyond this period, the chance for the person to acquire a language will get much harder.

However, the hypothesis lacks empirical evidence and is a controversial issue in bilingualism and second language acquisition. If we relate this hypothesis to the human biological development, especially the brain, it may give us a clearer idea of the hypothesis. Woods \& Carey (1979) state that children recover more 
quickly and more fully from aphasia than adults and this is because the brain of a child is not yet fully developed whereas the adult brain has fully developed. This means that the child's brain has a greater plasticity compared to the adult's brain; therefore other parts of the brain can take over the functions of the damaged one (Hoff, 2014). Moreover, Penfield \& Roberts (1959, cited in Hamers and Blanc, 2000) assume that an early language learner's ability to learn a language with ease is because of the relatively greater cerebral plasticity that the child has. In sense to this, an early language learner's brain has not neurologically matured thus giving the learner greater flexibility in learning a language and making the learner easier in acquiring it as he or she has less linguistic baggage.

\section{Introducing English since Early}

A very appropriate approach in learning English for early childhood is the Total Physical Response (TPR) approach developed by James Asher in 1977. This approach involves the child's activities specifically as a response to instructions or something that is being learned. In introducing English to children through learning English for young children, the application of songs, chants and rhymes (songs and songs) can be used. The term song is often interpreted as a song or song. While chant can be translated yells that can add to the spirit. Rhyme can mean a song with a certain rhyme, usually has the same final sound on several or each line. Chant and Rhyme can be formed from poetry.

Songs and songs are very useful and effective activities for language learning for young children. In language learning, this activity is very useful especially for children who have not been able to produce language. Singing activities can improve language development and physical development of the motor, especially if the activity is integrated with music and movement (dance). Singing activities can facilitate children with different learning styles; such as visual, auditory and kinaesthetic.

Singing is not something that is difficult to learn or do, even the child's daily life is inseparable from singing activities. The same thing happened in the education environment for AUD. Singing activities in English can be done to improve listening skills. This is in accordance with the suggestion that the skills that need to be prioritized in teaching English for early childhood are oral skills. Skills that include oral skills are listening skills and speaking skills. Singing activities can be combined with the application of the TPR (Total Physical Response) approach.

In practice, TPR provides broad opportunities for children to respond to instructions or instructions of teachers in English with physical movements. In this activity, children are not required to respond verbally. Thus, this activity can be done when early childhood is still in the stage of the silent period (silent period). In this period, children are actively learning through their sense of hearing by absorbing the language they hear as much as possible. However, despite having enough vocabulary, children are not ready to produce language both orally and in writing.

Children love song, rhyme and chant (Brewster, Ellis, \& Girard, 2002). Moreover, songs and songs have the nature of repetition and rhythm that are suitable for use as vehicles in language learning. This benefit makes many language recognition programs, especially for young children who implement singing activities. The benefits and potential of song, in learning English for early childhood, is to provide opportunities for children to learn while 
playing and undergo a pleasant learning process.

Selection of the types of suitable songs, chants and rhymes for children makes English learning for young children more meaningful and enjoyable. Singing is very useful to practice the child's ability to pronounce English words. In English there are stresses, rhythms and intonations that are different from Indonesian. By presenting singing activities, children can learn them in more fun and meaningful situations. Many songs can be used chant and rhyme in learning English for early childhood. Songs that are accompanied by movements can make children learn new vocabulary without having to be translated into Indonesian.

\section{CONCLUSION}

Introducing English to early childhood needs to be prepared by having teachers who understand the theory about the framework of early childhood development and also the development of the language. John Dewey, Maria Montessori, Erik Rikson, and Lev Vygotsky are experts in the field of cognitive development of children. These experts suggest that early childhood can learn well if given adequate facilities and educational facilities that are educated (educative).

Understanding of children's thinking framework can encourage teachers to use 'songs, chants and rhymes' as an effective, fun and meaningful learning media. The recommended approach and media for learning English for young children is the 'singing' approach.

\section{REFERENCES}

Cole, Michael., and Sheila R. Cole. 2001. The Development of Children. New York: Worth Publishers.
Cameron, Lynne. 2001. Teaching Language to Young Leraners. Cambridge: CUP

Goffman, Erving. 1990. The Presentation of Self in Everyday Life. Tersedia: http://en.wikipedia.org/wiki/Empirici st [29 Mei 2013]

Hamers, J.F. and Blanc, M.H.A. 2000. Bilinguality and Bilingualism $2^{\text {nd }}$ Edition. Cambridge University Press

Hermawan Warsito, Pengantar Metodologi Penelitian, (Jakarta: Gramedia Pustaka Utama, 1993), hlm 25.

Hoff, E. 2014. Language development. 5th edn. Wadsworth: Cengage Learning.

Lenneberg, E. H. 1967. Biological Foundations of Language. New York: Wiley.

Lexy Moleong, 2011. Metodologi Penelitian Kualitatif (edisi Revisi), (Bandung: PT Remaja Rosdakarya, hal, 6.

Sulistyo, G., H. 2009. Pembelajaran Bilingual pada Pendidikan Anak Usia Dini. Jurnal Kajian Teori dan Praktik Kependidikan, Vol.36 hlm. 1 82

Suharsimi Arikunt. 2005. Manajemen Penelitian, Jakarta: PT Rineka Cipta.

Rabbianty, Eva Nikmatul. 2015. Pembelajaran Bahasa Inggris Pada Anak Usia Dini di Sekolah Alam Exellentia Pamekasan Madura. Jurnal OKARA, Vol. 9 No. 1, hlm. 83-102.

Woods, B. T., \& Carey, S. 1979. Language Deficits after Apparent Clinical 
PEDAGOGI: Jurnal Anak Usia Dini dan Pendidikan Anak Usia Dini Volume 5 Nomor 2 Agustus 2019

P-ISSN: 2599-0438; E-ISSN: 2599-042X

Recovery from Childhood Aphasia. Annals of Neurology, 6, 405-409.

http://edukasi.kompas.

com/read/2012/05/02/1324267/Kemd
ikbud.Ingin.Cetak.Generasi.Emas

tersedia: Rabu 2 Mei 2013 